\title{
A Library for the Undergraduate College
}

Alexander Laing is assistant librarian, Dartmouth College Library, Hanover, N.H.

$\mathrm{H}^{\mathrm{OR}} \mathrm{MY}$ springboard I have chosen H Harvie Branscomb's Teaching with Books: A Study of College Libraries. I shall refer less specifically, now and then, to the symbolic stretch of shore line on which I found my springboard: the Dartmouth College Library. I say less specifically because my conclusions will not be drawn from the immediate scene of my own activities, with the assumption that what works well in Hanover, N.H., is to be recommended to all comers.

My title, "A Library for the Undergraduate College," implies that the undergraduate college requires a distinct type of library, and that the concept of what such a library should be and how it should differ from others is still formative. Mr. Branscomb says, "The function of the college library, and usually its financial exigencies as well, confine it to the preservation of books for its teaching program and for the direct use of faculty members in study and research." $\mathrm{He}$ makes the standard exceptions covering local and college history.

This summation, if we steadily bear in mind the implications of the words "preservation" and "direct," seems unexceptionable. The college library exists as the central working tool of a special educa- tional project, limited typically to four years commencing at about mid-adolescence. Except for minor aspects of one or two courses, the college will not expect of its library any books originally written for a lower mental age than that of college freshmen.

At this point it seems well to divide the large problem under its two component headings, and to deal with books and services separately before making summary remarks in which the two will be, as they should be in all fundamental decisions, viewed as inextricable parts of a single function again.

\section{Books}

Because collegiate instruction still has a not too vague upper as well as a strict lower limit, the choice of books for the direct use of undergraduates is further simplified. The occasional genius who persists in remaining in college, when he might advance more swiftly without its encumbrances, can be dealt with by the conscientious librarian as the occasion arises. But in planning within the limits of what is reasonably to be expected, another definite fence can be put up at the borders of languages specifically taught in the curriculum, and a wavering boundary can be indicated to define upper limits of abstruseness in works acquired for undergraduate use. This can be placed on a line perhaps a year beyond the farther 
reaches of any subject as it is taught in the prescribed curriculum.

All of the other choices seem relative, even when we consider the needs of the undergraduate alone, apart from the needs of his teacher. My private conviction upon one other limitation is presented with the warning that it may merely betray the narrowness of one who is himself no linguist. I think nevertheless that it is advisable in a library primarily meant for undergraduates to emphasize the acquisition of books in the language or languages native to the students themselves. For most American college libraries, the first English translation of Castiglione's Courtier should thus be considered more desirable than the original Italian edition. But all first editions are materials for special and later consideration.

When funds are not lavishly provided, the need for the college librdry to integrate its acquisition policy into close harmony with the teaching program is an evident first obligation. The entire problem of what to acquire, in many institutions, probably is as academic as the institutions themselves, because the faculty members know just what they want and are resigned to the realization that they had better put their requests in order of relative importance as all of their desiderata are not going to be supplied anyhow-at least until some years after the oldest and richest alumnus is bullied, by the saddest and weariest college president, into making the right kind of will.

The choice of books to be bought is thus perhaps the least vexatious of the many problems of a librarian who has accepted the axiom that his most obvious obligation is the maintenance of an up-todate working tool for a specific faculty engaged in teaching specific subjects.
The major problems affecting books as distinct from services in most cases can be summed up as those of inherited evil and those of unhoped-for bounty. The individual librarian usually starts with an appalling agglomeration representing at best the dead issues that were alive in other days, at worst the dubious generosity of zealots eager to clean out all roosting dodos from their own shelves. Into the sorrows of coping with such a clutter, there come on occasion the unexpected donations of real money for "something different"-sums with just enough strings affixed to restrain the librarian from applying them at all to the pressing needs of the moment.

Mr. Branscomb attacks all of these problems with vigor and ruthlessnessand, what is not so common, with the backing of cited facts from researches conducted by himself and other field workers. From a study of the circulation figures of five colleges of moderate size, he concludes that " 25,000 volumes correctly selected"-and the emphasis of italics is his-"would serve the undergraduate needs for the year of all five colleges, reference materials excepted, and I0,000 volumes would have taken care of any one of the colleges." $\mathrm{He}$ then cites with apparent approval a colleague's remark that "the college library of the future will be a continually changing collection of 25,000 volumes."

\section{What to Do with Moribund Book Stock}

This is the one point at which my series of "footnotes to Branscomb" enters the urgently dissenting phase. Mr. Branscomb, I gather, would indiscriminately dump all volumes of sermons that had come to the library as gifts. But I cannot, as a regretful agnostic, feel so bitter about old 
sermons as some of my friends do who expose themselves to new sermons more often than I. And I shall want a far better guide than my own conscience in judging the value of anyone else's field with such inclusive ruthlessness.

College faculties, as college librarians are so glumly aware upon both aspects of the simile, are like stagnant ponds fed by a few clear underwater springs. Seasonally those faculty ponds have a habit of "working"-and all manner of strange old stuff comes up from the bottom: decaying leaves of other heydays, and peculiar slimy forms of primal life. It all disappears in due course, and the ponds are placid and stagnant again except for the few clear hidden springs known only to those who swim around in the ponds themselves. But the working brings changes each time it occurs. Things that had sunk to the bottom out of sight and mind are for a while on the surface once more.

As an instance, I can cite the renewed interest, in several of our eastern colleges and universities, in the curious naive novels written by Americans in the early nineteenth century. These are wanted for use in teaching, for assignment on the reading lists. One of the largest and oldest universities considers them so important that booksellers of my acquaintance firmly believe that its library will buy any such items it lacks, and at a fancy price. Consequently the prices have become fancy, just at the time when the faculty of my own college is beginning to evince a strong interest.

Five years ago, if I had let my conscience be my guide in winnowing down a collection of inherited goods and evils, with the specific object of saving what would be of use in active teaching, I should almost certainly have junked those quaint, self-conscious novels. Whatever their special appeal might have been as New Hampshire imprints, or raw material for the social historian, it certainly would not have occurred to me that they would be placed at the reserve desk by order of teachers of English literature.

There is obviously no telling or foreseeing what parts of a moribund book stock will reattain dignity, perhaps of a new and different sort. This of course is axiomatic in the great university and public libraries to which Mr. Branscomb refers as the proper custodians of all acquirable knowledge, but it is an axiom which cannot be wholly disregarded by the college library either, even though the main controlling method does turn upon the retention only of those books that are useful in active teaching.

Finally, I thought to point out Mr. Branscomb's candid discovery that it costs almost as much to throw a book away as to build new stack space for its retention. Common experience makes it not difficult to regard the estimate of fifteen to twentyfive cents per volume as being roughly correct for any library which goes in for thorough cataloging. A cataloger's time costs a cent or more a minute. Many books have four or more cards to be hunted down and removed. The probability that there are cross reference cards in some instances makes the routine search for them advisable in every case, if the catalog itself is to remain accurate. Then there is the time to be spent in finding the book itself and removing the marks of ownership, to say nothing of the probably more highly paid time originally spent in deciding that the book must go.

These considerations lead me to think that the average cost of discarding a book 
would be nearer twenty-five cents than fifteen. And there is no reason for doubting a professional stackbuilder's estimate that twenty-five cents per volume is the average new stack cost. Having published his estimate, he would have a hard time exceeding it when requests for bids were sent out from the college treasurer's office.

So-in the most pungent phrase of a depression era-what? For one thing, these various considerations confirm me in an old opinion that is not even original. While I share Mr. Branscomb's not-so-old belief that an efficient library for an undergraduate teaching faculty should be compact and should be kept compact by a constant jostling of the dodo roosts, I think he errs, both in ideal and in practical tactics, when he implies a need for the continuous outright discarding of books not in active use. The fact that this cannot be defended even on the basis of economy provides a lesser, but also a finally decisive argument against it.

\section{Open Stacks and Dodo Repositories}

Far better, it seems to me, is the plan, already much discussed and to some degree in use, which calls for a compact, active, open-stack library kept continuously attuned to current teaching needs, but maintained in conjunction with other repositories for materials so valuable or abstruse, or of such doubtful present usefulness, that they do not belong in any open stack maintained for strictly collegiate purposes.

Experience at Dartmouth is inevitably pushing us in that direction. But here again I must emphasize the untypical nature of our own situation. To attain the downward optimum of 25,000 volumes recommended by some for an under- graduate library, we should have to discard 95 per cent of our books, which seems a trifle drastic. We do find, however, that in holding tenaciously to the openstack principle we are progressively defeated by the very size of the collection. For one thing, it has made necessary the conversion of our classification scheme from one of the simpler to one of the more ramified systems, scattering into several widely located sections books of a related nature that once were grouped under a vaguer heading in one place. For another, the smaller groups have again grown to a size which bewilders the simple-hearted seeker for two or three titles on his subject. Picking at random, he is certain to get a preponderance of books beyond his scope.

The remedy with us, however, is the same as that which can be recommended to those who start with a collection so near the 25,000 optimum that the idea of outright discards may seem practical as well as attractive to them. I should like to see the open stack of the Dartmouth College Library carefully studied, with the active cooperation of the whole faculty, and reduced to a working undergraduate library of much smaller proportions, from which books would thereafter be subtracted at about the same rate as that of acquisitions. Whether the books removed in the first great purge and successive minor ones should be again subdividedinto presumptive dodos, and suspects for the abstruse and valuable categorieswould be largely a matter of local convenience. And because at this point we are merging into questions of service, the transition would best be indicated.

As a means of doing so, as well as to remove any possible false impression arising in my quotations from intermediary 
phases of Mr. Branscomb's argument, I want to quote the summary Mr. Branscomb gives of his own opinions on the subject of book stock.

"The ideal," he says, "would seem to be to have available all books vitally related to the subjects of the curriculum that can be secured." $\mathrm{He}$ adds the following "undebatables:"

a. The desirability of eliminating numerical goals in either direction

b. The continual removal of books that have obviously ceased to be of value

c. Expansion only on the basis of need and actual use

With the first I am in full accord, adding only the footnote that a tendency to err in either direction would be better steered toward compactness. To the second I add the serious codicil, for which I have already argued at length, that books removed should not mean books discarded - that the dodos should be placed in retirement from which any that summon enough energy can scramble back to the active collection again. To the third summary no footnote seems necessary, beyond the remark that those college libraries which have the means for expansion on a broader basis than need and actual use should let the expansion flow into stack areas separate from the active undergraduate open stack.

\section{Service}

Frank recognition of the value of an undergraduate open-stack collection as the central device of an exclusively collegiate library removes from argument some of the problems that have most vexed us at Dartmouth-including the most knotty of all: the effort to come to any conviction whatever, in practical terms, as to the distinction between materials required for teaching and for research. When the primary importance of the central active collection has been acknowledged by both teachers and librarians, through their cooperation in establishing and controlling it, all demands for new material should assort themselves automatically on a basis of whether or not the recommender of the book wants it put in the active teaching collection or in one of the special sections. If it is not to go into the undergraduate library, the presumption is that it is acquired for research.

This supplies an automatic answer to the occasional critics, some influential, who suspect that college librarians wilfully buy research materials in preference to books that the boys and girls themselves conceivably might be expected to read. A library of predetermined size, always full, and never added to without a corresponding subtraction, would be less likely to be made the subject of complaints of neglect than one in which the critics have no real means of knowing or seeing, in segregation, the books that are intended for the undergraduates and those that are not. Similarly, if the undergraduate library is admitted to precedence, and its champions are kept satisfied, the percentage of funds available to be spent on research material takes care of itself, whether or not the turnover of the undergraduate collection is rapid. In years when it is rapid, the research collection will have slimmer pickings-and that, granting our premise, is as it should be in an undergraduate college library.

\section{Importance of the Subject Catalog}

What will the catalogers have to say of these proposals? They will be supplied with a dangerous argument against the compact open-stack collection if we claim 
that a special catalog for it is necessary. I therefore advise a concurrent effort in cataloging to meet the undergraduate mentality on its own terms. This mentality thinks of books in terms of subjects first, then titles, with authors last. I think that reference librarians will bear me out when I say that the vague seeker for a half-forgotten book is likely to have his information about it arranged in that descending order of assurance.

Thus a library for the use of undergraduates should put primary emphasis upon a subject catalog-by which I do not mean subject cards in the main cata$\log$. As a library grows larger, even the most lucid of cataloging arrangements results in areas-under "Bible" and "Shakespeare" and certain general headingsthat become the despair of the user. Branscomb cites an instance of 500 cards all headed "Organic Chemistry." And nobody could conceivably be less helped by that than an organic chemist!

\section{The Ideal}

The ideal, if someone can work it out in terms of a system, would be to have the shelving arrangements in the active teaching collection based upon fairly general groupings that would bring comparable subjects together, while the subject index would be based on more particularized headings. Organic Chemistry, in such a selective library, would be a not unreasonable grouping for the books themselves, but would still be silly in the subject catalog.

To be more specific, I have mourned the dispersal, in the library where I work, of the books that were assembled under an old heading which probably was designated as "Nautical." Today, under our more efficient classification, works on shipbuilding are divided between Architecture and Carpentry; Navigation and Seamanship have their widely separated roosts; Voyages have gone down with Geography-and various subclassifications of history have absorbed most of the rest of a batch of books once all happily together for the convenience of an individual whose main interests still, despite sub-subclassifications, can be summed up in the one word Nautical.

It seems to me unquestionable, then, that an effort to segregate an active working library should not be in part frustrated by adherence to the classification schemes admittedly evolved for large collections.

To sum up specifically, I should recommend the maintenance of a complete author and title catalog in one alphabet, and a separate subject catalog at least for the active collection.

To save time, I am taking agreement for granted on the high desirability of many aspects already emphasized in college libraries: the browsing collection of classics and current works, the project schemes for instruction in the use of research and reference materials, the increasing importance of the reserve desk. It is growing clearer every year with us at Dartmouth that the process of teaching is moving deeper and deeper into the library itself, and I recommend to you, along with the rest of his book, evidence presented by Mr. Branscomb of the necessity for a complete coordination of the formerly separate functions summed up in the persons of librarian and dean. The perfect answer well may be that devised at Stephens College, cited by Mr. Branscomb, where the librarian is the deannot by happy accident, but by deliberate policy. 


\section{Coordination}

When it is admitted that the library is primarily the tool of the teaching faculty, obviously the central philosophy of instruction of a particular college must be the guiding influence in deciding most questions of choice and emphasis. But where it is evident, as I think is too generally the case, that the college itself is conscious of transition-is losing one philosophy and forming another-then certainly it becomes both the right and the duty of the librarian to lead as well as to serve in the formulation of new assurances. One thing seems evident in the popularity of honors and project courses: that recent arbitrary distinctions between the teachers and the taught are breaking down and being replaced by an older, perhaps wiser emphasis upon the relationship between the philosopher and his "school" in the antique sense. Faculty and undergraduates are again regarding themselves as co-workers in the fields of knowledge, the older men putting their greater experience at the disposal of the younger, with less emphatic assurance about what is and is not so. A good teacher said to me the other day that the difference between himself and his students is chiefly that they find no embarrassment in feeling sure of what they think are facts.

To put the large issue provocatively, and bring down on my luckless head the anger of many quasi-authors, I shall propose in view of this trend that it is the great project of the college library to eliminate the textbook and textbook teaching from the college scene. To quote a recent Dartmouth poet,

Now that the pattern's broken, and the hill Lies curving shadow to the bomber's wing,

we must all be more acutely aware than ever that in a broken-patterned world even the central information on any subject can seldom be sorted down to a few hundred orderly pages tricked out in a little buckram coat. Perhaps the days of belief in final authorities will return. Perhaps the social pattern referred to by Reuel Denney, in his compact two-line judgment upon his generation, will reassemble itself, and we shall again have a sense of certainties. Until then, I believe that the best kind of teaching will find the teacher frankly presenting himself as one in quest of the facts and in hope of finding the truth-one who invites the student to share the task of gathering and inspecting all available data that may lead again toward the lost goal.

Have I made myself plain? If not, let me put it this way: How many of us, without feeling like miserable charlatans, can look in the eyes of college youth today and claim that any teaching faculty knows what the useful, important facts are that control the orderly processes of our world? Orderly? Look at it!-at home as well as abroad-and prognosticate, if you will, how far the shadow of the bomber's wing will range, and in how many libraries it will darken the light.

It is a time for even college librarians to remember that they are librarians first of all, and that the best and most efficient service to the current needs of a teaching faculty may be less important in some respects than the maintenance, for that faculty itself, of books and principles it may want very much indeed to revive at some future date when the present swift changes of mind and method have settled down again to a sense of permanent values. Is there anyone in whom that sense of permanent values, of general truths, ought more logically to subsist than in the 
custodian of books-all books, new and old?

\section{Speeding Intellectual Transition}

College has ceased to be the pinnacle of education, even for the youth intended for business. It is now admittedly a transitional and incomplete phase of instruction that stops at an illogical point for most students, merely because they have not the means or the inclination to continue into graduate schools that now cover commerce in all its aspects as well as the professions. Whether or not the college student intends to continue into graduate school-and most do not-it holds true that colleges are shaping themselves more and more into places of transition. Somewhere in the college course it is expected that the process of acquiring alleged facts by rote, under outer compulsions, will evolve into the true student's method of learning by inquiry from inner impulsions.

The old theory seems to have been that this transition was managed mystically, somehow, on graduation day; that a presumptive child needing careful guidance then became all at once a presumptive adult, expected to guide himself whether in further schooling or in the active world.

But nowadays, I think the librarian can legitimately consider it as his function, quite apart from the specific activities of classroom teachers, to do everything in his power to speed that transition. For it is really the beginning of education. Once it has occurred, the preceptor is increasingly superfluous and a library alone will do the job. When the change has comeand $I$ have reasons for believing that it can come years earlier in many cases than it does now-the college library itself enters into a function, for the particular student, which has been the same in every library from the beginning of time: the function of making easily available, for the average user, as much as possible of the whole record of human thought.

It is upon this consideration, of the college library's possibilities for individual students who early free themselves from the small horizons of rote classwork, that I make my only strong stand against $\mathrm{Mr}$. Branscomb's excellent summation of what the college library is and what it should be.

Until the colleges themselves are more sure of their teaching policies and philosophies, I think we should err on the side of the unpredictables, striving at every point to honor the librarian's general creed : that in amassing and keeping usable the evidences of human thought, he shall not presume to judge the relative merits of different kinds of subject matter. Mr. Branscomb would let all the gift volumes of sermons go. I am not so sure. Hidden away in one of them, like the palimpsest in the spine of an ancient binding, there may lie the prescription that will really save our world at last from the bomber's wing. But I want the prescription to be found by a college student. 